WORKING PAPER - NO. 2020-81

\title{
Who CARES? Evidence on the Corporate Tax Provisions of the Coronavirus Aid, Relief, and Economic Security Act from SEC Filings
}

John Gallemore, Stephan Hollander, and Martin Jacob JUNE 2020

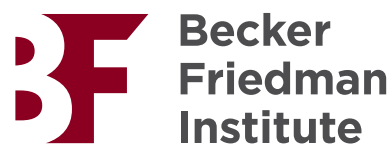




\title{
Who CARES? Evidence on the Corporate Tax Provisions of the Coronavirus Aid, Relief, and Economic Security Act from SEC Filings
}

\author{
John Gallemore \\ University of Chicago \\ john.gallemore@chicagobooth.edu \\ Stephan Hollander \\ Tilburg University \\ s.hollander@tilburguniversity.edu \\ Martin Jacob \\ WHU - Otto Beisheim School of Management \\ martin.jacob@whu.edu
}

June 2020

We thank Merle Erickson, Eva Labro, and Ed Maydew for helpful comments. John Gallemore gratefully acknowledges the support of the Charles E. Merrill Faculty Research Fund and the Accounting Research Center at the University of Chicago Booth School of Business. 


\title{
Who CARES? Evidence on the Corporate Tax Provisions of the Coronavirus Aid, Relief, and Economic Security Act from SEC Filings
}

\begin{abstract}
We use U.S. Securities and Exchange Commission (SEC) filings to provide initial large-sample evidence regarding utilization of corporate tax provisions by U.S. firms under the Coronavirus Aid, Relief, and Economic Security Act (CARES). These tax provisions were intended to provide firms immediate liquidity to prevent widespread bankruptcies and layoffs in response to the COVID-19 pandemic. However, critics have argued that the provisions were poorly targeted and amounted to "giveaways" for shareholders of large corporations. We find that 38 percent of firms discuss at least one of the CARES tax provisions in their SEC filings, a result primarily attributable to the net operating loss (NOL) carryback provision. Firms experiencing lower stock returns during the COVID-19 outbreak are more likely to discuss CARES tax provisions, but not firms in states or industry sectors exhibiting large increases in unemployment. Further, we find a higher likelihood of tax provision discussions for firms with pre-pandemic losses and higher financial leverage. Finally, we document some evidence that firms facing potential reputational or political costs from discussing these tax provisions may have avoided doing so. Our analyses suggest that tax provisions under CARES were not material for most publicly-traded U.S. firms, were not likelier to benefit firms in greater need of liquidity during the pandemic, and that some firms perceived that disclosing benefits would be costly. These findings are important for policymakers as they consider additional economic relief for U.S. corporations while the coronavirus pandemic lingers.
\end{abstract}

Keywords: tax policy, net operating loss, payroll tax, economic stimulus, COVID-19, pandemics, disclosure, political costs

JEL Classification Codes: H12, H25, H51, H84, I18, M41 


\section{Introduction}

We provide initial large-sample evidence regarding the corporate tax provisions in the Coronavirus Aid, Relief, and Economic Stimulus Act ("CARES"), which is the largest economic stimulus in U.S. history (Cochrane and Fandos 2020). Signed into law on March 27, 2020, CARES was passed in response to the COVID-19 pandemic in the United States, which to date has caused over 100,000 deaths. The pandemic has substantially impacted the American economy as well: the unemployment rate increased by over 400 percent and GDP declined at an annualized rate of 4.8 percent during the first quarter of 2020 . Among its many provisions, CARES includes several corporate tax breaks, including the ability to recoup past income taxes paid, defer certain payroll taxes, and receive tax credits for retaining employees. Ostensibly, these provisions provide immediate relief to firms impacted by the COVID-19 pandemic, in order to minimize layoffs or bankruptcies which could lead to a deeper and longer economic crisis. Proponents of these tax provisions note that they would "speed up" the process of providing liquidity and economic relief to corporations (Bjorhus and Kennedy 2020), and trade organizations have called for additional corporate tax breaks to "further inject liquidity" and "encourage the retention and rehiring" of employees. ${ }^{1}$

However, these corporate tax provisions have also attracted intense criticism. Since several provisions were targeted at firms with pre-pandemic losses or higher financial leverage, it is unclear whether they will benefit sectors and regions hardest hit by the pandemic. Others note that the primary beneficiaries of these tax provisions are likely the owners of corporate stocks, who are generally higherincome individuals (Sloan 2020). The director of the Institute on Taxation and Economic Policy slammed the tax provisions, claiming that they were "ridiculous... giveaway[s] for corporations and businesses" (Bjorhus and Kennedy 2020). Senator Sheldon Whitehouse of Rhode Island stated that "[t]he more you look at [the NOL provision], the more it smells," and has introduced legislation that would reduce firms' benefits from the tax provisions (Rubin 2020).

Providing evidence on the CARES corporate tax provisions-including how many firms benefit

1 The Retail Industry Leaders Association sent a letter to Congressional leaders on April 16, 2020; see www.rila. org/coronavirus-resources-for-retailers/rila-congress-proposals-to-assist-retailers-reopen. 
from them, which provisions they benefit from, and whether tax provision benefits flow to the sectors and regions hardest hit by the COVID-19 outbreak-is critical in evaluating the efficacy of CARES and in providing guidance to policymakers as they consider additional economic relief to prevent widespread bankruptcies and layoffs that could harm the economy for years to come. To study the CARES tax provisions, we use publicly-traded U.S. firms' SEC filings. If a firm materially benefits from one or more of the CARES tax provisions, they should discuss them in either their quarterly or annual filings (Forms 10-Q and 10-K, respectively) or in "current reports" filings (Form 8-K). We identify discussions of CARES in SEC filings from March 27 to May 31, and search these discussions for mentions of the tax provisions.

First, we explore when, where, and which CARES tax provisions are discussed by firms. We find that firms are slower to discuss the tax provisions than CARES at large or its lending programs. Over 80 percent of the tax provision discussions occur in 10-Q filings, suggesting that firms generally viewed the tax provisions as not having an immediate material impact, and waited to discuss them until their quarterly filings. Only 38 percent of firms discuss at least one tax provision, with the NOL carryback being the most common (25 percent). The other tax provisions were discussed by fewer than 15 percent of firms. While the NOL carryback provision can provide liquidity, it only applies to a subset of firms. In contrast, the two provisions with the broadest applicability and greatest potential for encouraging firms to keep employees on payroll (the payroll tax deferral and employee retention credit) were not discussed by over 85 percent of our sample. This suggests that the CARES tax provisions may not have been successful at providing material liquidity and encouraging employee retention for a broad sample of publicly-traded U.S. firms.

Next, we explore which firms are likelier to discuss CARES tax provisions. Consistent with several provisions being more applicable to certain firms, we find that firms with pre-pandemic losses and higher financial leverage are likelier to discuss the NOL carryback and interest deduction provisions, respectively. Furthermore, we find that firms operating in sectors experiencing lower stock returns during the pandemic were likelier to discuss the tax provisions. In contrast, we find little evidence that firms operating in sectors or states with greater unemployment increases are likelier to discuss the tax provisions other than the retention credit. These findings cast doubt on the idea that the benefits of the CARES tax provisions, and 
in particular the NOL carryback, primarily flowed to regions and sectors with greater unemployment, and instead suggest that they primarily benefitted firms whose stock prices had declined during the pandemic.

Finally, we explore whether firms that were likely eligible for certain CARES tax provisions avoid discussing them in their filings. We find some evidence that firms with greater pre-pandemic shareholder payouts and during-pandemic lobbying are less likely to discuss the interest deduction provision. This suggests that firms facing potential reputational or political costs from discussing CARES tax provision benefits may have strategically avoided doing so.

Our study should be useful to policymakers as they consider future economic relief and stimulus. Altogether, our findings cast some doubt on the idea that CARES corporate tax provisions, and in particular the NOL carryback provision, were successful in providing immediate and material economic relief to a majority of publicly-traded U.S. firms, and especially those that likely needed it the most. That said, it is important to note that our descriptive approach and proximity to the pandemic means that our analyses cannot fully speak to the efficacy of these provisions in mitigating the pandemic's economic impact.

Our paper is related to the nascent literature on CARES and other government actions taken to address the impact of the COVID-19 pandemic on U.S. corporations. Prior work has focused on either provisions aimed at individuals, such as stimulus payments and expanded unemployment benefits (Ganong, Noel, and Vavra 2020; Baker, Farrokhnia, Meyer, Pagel, and Yannelis 2020), or small businesses, such as the Paycheck Protection Program (PPP) (Barrios, Minnis, Minnis, and Sijthoff 2020; Granja, Makridis, Yannelis, and Zwick 2020; Bartik, Bertrand, Cullen, Glaeser, Luca, and Stanton 2020; Humphries, Neilson, and Ulyssea 2020). Our study is also related to the literature examining the usage of tax policy in response to recessions (Eilbott 1966; Romer and Romer 1994; Auerbach and Hassett 2002; Auerbach 2009). We contribute to these literatures by providing important initial evidence on the materiality of the CARES tax provisions and its heterogeneity across firms, sectors, and regions.

\section{Background on the CARES corporate tax provisions}


We focus on the five major CARES business tax provisions. ${ }^{2}$ First, CARES permits firms to defer payroll taxes (e.g., the Federal Insurance Contributions Act tax which funds Social Security and Medicare) until 2021 and 2022 (with 50 percent due in each year). This provision helps preserve liquidity for firms that otherwise would submit these payments to the IRS during 2020. Another provision allows firms to obtain a refundable payroll tax credit for 50 percent of wages up to $\$ 10,000$ per employee during the period from March 13 to December 31, 2020. For firms that averaged over 100 employees in 2019, this credit only applied to employees retained but not currently working. This tax credit encourages firms to keep employees on the payroll during the pandemic.

Several other provisions had more limited applicability. First, CARES allows firms to carry back tax losses in 2018 and 2019 and receive immediate refunds for prior income taxes paid in the prior five years. ${ }^{3}$ Another provision relaxes the limitations on the tax deductibility of debt interest. The Tax Cuts and Jobs Act (TCJA) of 2017 limited the interest deduction to 30 percent of adjusted EBITDA. CARES raises the cut-off to 50 percent for 2019 and 2020. Some firms immediately benefit in the form of a lower tax bill in 2019, while others can benefit by having a lower cost of debt, enabling them to raise funds at less cost to finance operations during the pandemic. The final provision dealt with the Alternative Minimum Tax (AMT). The TCJA repealed the AMT and provided refunds for any AMT credits over a period of several years, ending in 2021. CARES allowed firms to recover these AMT credits immediately, providing a liquidity benefit in the form of a refund or a reduction in tax obligation for 2019.

\section{Data and results}

\subsection{Methodology and data sources}

To examine the CARES corporate tax provisions, we employ SEC filings. U.S. securities law requires that firms disclose material information in a timely manner, where materiality is usually interpreted

2 There were several other minor business tax provisions, including greater deductibility of charitable contributions and deductions for payments towards employee student loan debt. We do not examine these provisions in this study, as they were unlikely to be a significant source of immediate economic relief for publicly-traded U.S. firms.

3 The TCJA had ended firms' ability to carry back NOLs. CARES also allowed firms to carry back losses that occurred in tax year 2020, but this would not provide firms with a benefit until they filed their 2020 tax returns. 
as a reasonable person considering the information substantially important. Material information can be discussed in either the financial statements or the management discussion and analysis section in annual (Form 10-K) or quarterly (Form 10-Q) reports (Heitzman, Wasley, and Zimmerman 2010). Alternatively, firms are required to file a Form 8-K within five days of a material event (Lerman and Livnat 2010). Therefore, firms discussing a CARES tax provision in an SEC filing likely suggests the provision materially impacted the firm. By employing SEC filings, we can provide a timely measure of the relevance and impact of the CARES tax provisions for a large sample of publicly-traded U.S. firms.

We analyze all 10-Ks, 8-Ks, and 10-Qs filed with the SEC during the period from March 27 to May 31. We search these filings for mentions of CARES, either in its full or abbreviated form. We identify 1,917 filings during this period that reference CARES. ${ }^{4}$ We extract 30 words before and after these mentions to build a repository database of CARES discussions. This allows us to capture the context of CARES discussions, including the specific provisions that are relevant for the firm and whether the firm expects to benefit from those provisions. ${ }^{5}$ We search these discussions for words or phrases associated with the specific tax provisions, non-tax CARES provisions (e.g., PPP), and discussions of the firm's expected benefits from the Act's provisions. Appendix A provides the list of terms used to classify these discussions and some example discussions for each tax provision. Finally, we aggregate these discussions across all of the firm's filings during our sample period.

We assume that SEC filings will only discuss CARES tax provisions with a material impact on the firm. One concern is that a firm may mention a CARES tax provision while indicating that it is still evaluating CARES or has determined that it will not benefit from the provision. If so, then counting tax provision discussions would overstate the actual number of firms that expect to benefit from them. To explore this idea, we search for the presence of certain words indicating whether the firm appears to be

This represents 19 percent of the total Form 10-Ks, 10-Qs, and 8-Ks filed during this period.

5 One concern is that a firm begins a discussion of CARES by mentioning the Act, but then does not refer to it again as it continues to discuss the Act's relevant provisions. Manual inspections of filings discussing CARES suggest that firms usually repeat the Act's name several times throughout the discussion of the Act, suggesting that our approach likely captures the entire discussion related to CARES. 
certain that it will or will not benefit from the tax provisions, or whether it was still evaluating the applicability of the Act. ${ }^{6}$ Only 13 percent of firms indicate that they are still evaluating CARES and less than 10 percent of firms state that they will not benefit from the Act. This suggests that disclosures from a non-benefiting firm are an unlikely source of measurement error in our analysis, and is consistent with firms not being required to disclose factors that do not materially impact their operations. ${ }^{7}$

We employ several additional datasets in our analyses. We employ financial accounting and stock market data from Compustat and CRSP, respectively. We obtain data on state-level COVID-19 cases from The New York Times, unemployment data from the Bureau of Labor Statistics, and lobbying data from OpenSecrets. ${ }^{8}$ For a firm to make it into our final sample, it must have filed at least one Form 10-K, 10-Q, or 8-K from March 27 to May 31, and have non-missing values for the variables used in our analyses. We also exclude financial firms (SIC code beginning with 6), as these firms generally talk about CARES in terms of their role as a lender in distributing PPP funds. Our final sample contains 1,813 firms (representing more than 90 percent of total market capitalization for non-financial firms), of which 66 percent discuss CARES in at least one SEC filing. We present descriptive statistics for the variables used in our study in Table 2. All variables are defined in the Appendix.

\subsection{When and where do firms discuss CARES tax provisions?}

We begin by exploring when and in what SEC filings firms discuss CARES tax provisions. In Figure 1, Panel A, we explore the CARES-related disclosures over our sample period by plotting the cumulative number of filings by each date that contains discussion of at least one CARES tax provision. For comparison, we also plot the similar cumulative counts of filings with any CARES mention or a mention of a CARES lending program (e.g., the PPP). We find that the number of filings discussing the tax

6 For example, we classify discussions containing words such as "evaluating" or "reviewing" as indicating the firm is still evaluating CARES, and those with phrases such as "do not," "did not," or "will not" near words such as "benefit," "effect," or "impact," as indicating that the firm will not benefit from the tax provisions.

7 In all analyses except for Figure 1, we set provision discussion variables equal to zero if the firm indicates that it does not expect to benefit from CARES.

8 These data can be found at the following websites: https://github.com/nytimes/covid-19-data (New York Times) and https://www.opensecrets.org/news/issues/covid-19 (OpenSecrets). 
provisions generally lags the number of loan program filings until late in our sample period. In Figure 1, Panel B, we plot the percentage of filings of each filing type discussing CARES, its tax provisions, or its loan programs. We find that the tax provision discussions most frequently occur in quarterly filings (80 percent), with the remainder generally in "current report" filings. In contrast, discussions of the loan programs are split equally across 10-Qs and 8-Ks. The low occurrence of annual reports is not surprising, as most have filed their 10-Ks prior to our sample period. These findings indicate that the loan programs, which could result in substantial amounts of new loans, generally warranted immediate disclosure. In contrast, firms on average viewed the impact of the tax provisions as not warranting an 8-K filing and therefore waited until their quarterly filings to discuss them.

\subsection{Which tax provisions do firms discuss?}

In Figure 2, we plot the percentage of firms that have at least one disclosure discussing a CARES tax provision. The NOL carryback was the most referenced tax provision ( 25 percent of firms), suggesting it was the most relevant provision for publicly-traded U.S. firms. While this provision does allow firms to obtain immediate liquidity via refunds for prior taxes, only firms with pre-pandemic losses qualify. In contrast, the provision that was widely applicable in theory (payroll tax deferral) and the provision directly aimed at firms to encouraging employee retention on payrolls (retention credit) were only discussed by 14 percent (9 percent) of firms with an SEC filing during our sample period. ${ }^{9}$ Untabulated findings suggest that only 15 percent of firms discuss multiple tax provisions. While it is possible that firms materially benefitted from these provisions without discussing them, this evidence questions whether the CARES tax provisions provided economically important relief for a broad sample of listed U.S. firms. ${ }^{10}$

9 The low incidence of employee retention credit discussions could be driven by several factors. First, there was initially uncertainty over whether firms that paid health care benefits but not wages could claim the credit; on May 8, the IRS clarified that it applied to health care expenses. Second, firms that received PPP loans and did not repay them by May 18, 2020 were ineligible for the credit. Third, the benefit may not have been material.

10 We also analyze the amount of benefit by manually inspecting dollar amounts near CARES tax provision discussions. We are able to identify 47 instances in which a sample firm clearly indicates a dollar benefit associated with a CARES tax provision, a majority of which are associated with NOL carrybacks. The mean (median) benefit is $\$ 34$ (\$13) million, although it ranges from \$1 million to $\$ 411$ million. However, we note that firms vary widely in how they discuss these benefits (e.g., cash vs. accrual, immediate benefits vs. total benefits, etc.), and thus we recommend interpreting these amounts cautiously. 


\subsection{Which firms discuss CARES tax provisions? Sector and state-level pandemic exposure}

Next, we examine whether the discussion of CARES tax provisions varies across sectors and states. In Figure 3, we explore whether firms operating in sectors impacted more by the pandemic were likelier to discuss the tax provisions, using two measures of sector-level impact: (1) Sector Stock Returns, the valueweighted stock return from December 31, 2019 to March 24, 2020 (Panel A), and (2) 4 Sector Unemployment, the change in the unemployment rate from December 31, 2019 to April 30, 2020 (Panel B). ${ }^{11}$ We then plot each sector measure on the $\mathrm{X}$-axis and the percentage of firms in that sector that discuss at least one tax provision on the Y-axis. We find evidence consistent with firms in sectors experiencing lower stock returns in 2020 being likelier to discuss CARES tax provisions. However, the economic significance is relatively modest: a 10-percent decline in sector-level stock returns is associated with a 5percent increase in firms discussing CARES tax provisions. In contrast, we find no association between the change in the sector's unemployment rate and the percentage of firms that discuss tax provisions. We also examine whether the tax provisions benefitted the U.S. states impacted most by the pandemic. In Figure 4, we plot the percentage of firms in each state that discuss at least one of the tax provisions on the Y-axis, and two measures of the state-level pandemic impact on the X-axis: (1) State COVID-19 Cases, the number of COVID-19 cases per capita, measured as of April 30, and (2) AState Unemployment, the change in the state-level unemployment rate from December 31, 2019 to April 30, 2020. Neither association is economically or statistically significant, suggesting that firms operating in states more affected by the pandemic were not likelier to materially benefit from the tax provisions.

\subsection{Which firms discuss CARES tax provisions? Firm-level factors}

Next, we explore whether certain firm characteristics are associated with the discussion of CARES tax provisions using multivariate analyses. Specifically, we regress an indicator variable equal to one if the firm discusses a CARES tax provision on several sets of variables. First, we include variables that identify

11 We stop calculating stock returns as of March 24 because the uncertainty regarding CARES was substantially resolved on the morning of March 25, and therefore returns after March 24 may have been impacted by CARES. We measure unemployment through April because this represents the peak unemployment rate during the pandemic. When examining sector-level unemployment, we use the BLS's sector definition. 
firms that likely benefitted from specific tax provisions: Loss 18/19, an indicator variable equal to one if the firm has either a loss in 2018 or 2019 and at least one year with a profit in the preceding five years; Leverage, the ratio of total liabilities to total assets in 2019; and Employees, the ratio of the number of employees to total assets in 2019. We expect Loss 18/19, Leverage, and Employees to be positively associated with discussions of the NOL carryback, interest deduction, and payroll tax deferral provisions, respectively. We include Size (natural logarithm of total assets) as larger firms are more likely to have the necessary human capital in their tax departments to quickly analyze and file for these tax benefits (Barrios and Gallemore 2019; Zwick 2018). We include two firm-level pandemic exposure measures: Firm Stock Return, the firm's stock return from the end of 2019 through March 24, 2020 (adjusted for Sector Stock Returns), and Cash Holdings, the ratio of cash holdings to total assets as of year-end 2019. Firms with lower stock returns over this period may have been more negatively impacted by the pandemic, and firms with lower cash holdings may be in greater need of the immediate liquidity the tax provisions provided. Finally, we include variables that capture sector-level and regional-level exposure to the COVID-19 pandemic: Sector Stock Returns, 4 Sector Unemployment, State COVID-19 Cases, and UState Unemployment.

We report these analyses in Table 2, using linear probability regression and clustering standard errors at the state-sector level (as the impact of the COVID-19 pandemic likely varies across states and sectors). ${ }^{12}$ In column 1 , our dependent variable is an indicator variable that captures whether the firm discussed any of the five tax provisions in at least one SEC filing during our sample period (Tax Provision). We find that Loss 18/19 and Employees (Sector Stock Return) are positively (negatively) associated with Tax Provision, indicating that firms with pre-pandemic losses, more employees, and operating in sectors with greater deteriorations in market value were more likely to discuss CARES tax provisions overall. None of the other determinants are statistically significant. In columns 2 through 5 , we examine the individual tax provisions separately (we omit the AMT credit, given its low incidence). When examining NOL Carryback in column 2, we find results in this column largely mirror those in column 1, which is not

12 Our inferences are unaffected if we instead use logistic regression or robust standard errors (results untabulated). 
surprising as much of the variation in Tax Provision is driven by NOL carryback discussions. Additionally, we now find that larger firms and firms with lower during-pandemic stock returns were more likely to discuss the NOL carryback provision. In column 3, we find that Employees (Cash Holdings and Sector Stock Return) is positively (negatively) associated with payroll tax deferral discussions. In column 4, we find that only $\Delta$ Sector Unemployment and $\Delta$ State Unemployment are positively associated with discussions of the employee retention tax credit, suggesting that this credit was more likely to materially benefit firms operating in states and sectors whose labor markets were harder hit by the pandemic. Interestingly, we find that Employees is not associated with employee retention tax credit discussions. This could be driven by the fact that the full benefit of the employee retention only applied to firms with 100 or fewer employees, meaning that the benefit of this provision was stronger for firms with fewer employees. ${ }^{13}$ In column 5, we find that firms with greater leverage are more likely to discuss the interest deduction provision, consistent with our expectations. We also find a significant positive (negative) coefficients State COVID-19 Cases (Size and Cash Holdings).

The findings in Table 2 provide several takeaways. First, finding a strong positive association for the expected determinant-provision pairings (Loss 18/19 with NOL Carryback, Employees with Payroll Deferral, and Leverage with Interest Deduction) provides validation for our textual classification methodology, and suggests that firms with recent losses, higher financial leverage, and more employees benefitted from certain CARES tax provisions. Second, we generally do not find an association between the measures of the firm's susceptibility to the pandemic (e.g., Employees or Cash Holdings) or the sector or state-level pandemic exposure (e.g., 4 State Unemployment) and the likelihood of discussing a CARES tax provision. There are two important exceptions: payroll deferrals, which was more likely to benefit firms with more employees and with lower liquidity, and the retention credit, which was more likely to benefit firms operating in sectors and states with greater increases in unemployment. However, we do find a strong negative association between the extent of deterioration in the firm and sector-level equity values and the

13 We find that 14 percent of our sample firms had employees of 100 or less in 2019. 
discussion of the NOL carryback rule. This suggests that the most discussed CARES tax provision-the NOL carryback rule — was more likely to materially benefit firms and sectors whose market values declined, but not firms with operating in sectors or states whose unemployment increased during the pandemic.

\subsection{Do some firms strategically avoid discussing CARES tax provisions?}

Finally, we explore whether some firms strategically avoid discussing CARES tax provisions. There are several reasons why a firm may not discuss a CARES tax provision in its SEC filings. For example, the tax provision may not be applicable, or the tax provision may apply but the expected benefit is not material. Indeed, prior research suggests that firms' propensity to disclose an item is increasing in the item's materiality (Gleason and Mills 2002; Heitzman et al. 2010). Alternatively, firms may expect a material benefit from a CARES tax provision but choose not to disclose it to avoid certain reputational or political costs, consistent with prior research suggesting that firms strategically disclose tax issues (Ayers, Schwab, and Utke 2015). For example, firms with large recent payouts to shareholders or significant lobbying expenditures may fear incurring public backlash from disclosing that they benefitted from the CARES tax provisions. Consistent with this idea, several articles and reports have scrutinized corporate lobbying around the CARES Act (Gross 2020; Fischer and Payne 2020; Evers-Hillstrom 2020).

To study whether firms strategically avoid discussing CARES tax provisions in SEC filings, we focus on the NOL carryback and interest deduction provisions. These two provisions have bright-line criteria for eligibility, allowing us to better identify firms that were likely to benefit from them. We regress the appropriate indicator variable - either NOL Carryback or Interest Deduction — on a set of variables capturing potential reputational or political costs. Importantly, to isolate strategic disclosure choices, we control for the expected materiality of these tax provisions (Heitzman et al. 2010). For the NOL carryback provision, we measure the expected NOL carryback, scaled by total assets (NOL Carryback Materiality). ${ }^{14}$ For the interest deduction provision, we calculate the additional interest expense that is now tax deductible

14 We calculate the expected NOL carryback as the cumulative loss over 2018-19 or the loss in 2019, whichever is applicable. Then, if the cumulative profits in the five years prior to the loss period are less than the absolute value of this loss, we set the potential NOL carryback as equal to these profits (or zero, if there is a cumulative loss). 
under CARES, scaled by total assets (Interest Deduction Materiality). ${ }^{15}$ We estimate these regressions on subsamples of firms for which the tax provision should be applicable. For the NOL carryback provision, we include only firms that we expect to carryback prior losses (Loss 18/19=1). For the interest deduction provision, we only include firms with an interest expense-to-EBITDA ratio greater than 30 percent in 2019.

We include several variables to capture potential reputational or political costs to disclosing a CARES tax provision benefit. First, we include Size; larger firms are more likely to suffer from reputational and political costs from tax-related issues (Zimmerman 1983). We include Payouts, the sum of payouts (dividends plus share repurchases) in 2018 and 2019 scaled by total assets, and Lobbying, the natural logarithm of expenditures for federal government lobbying in the first quarter of 2020. We include Low $E T R$, an indicator variable equal to one if the firm's 3-year cash effective tax rate over the period 2015 to 2017 is in the bottom quintile, and zero otherwise. ${ }^{16}$ Finally, we include Firm Stock Return. Firms with greater pre-pandemic payouts (which benefit shareholders but erode the firm's liquidity), greater duringpandemic lobbying expenditures and stock returns, and a lower pre-pandemic effective tax rate (suggesting greater tax avoidance) may be more sensitive to discussing a CARES tax provision benefit due to potential reputational or political costs.

We present these results in Table 3, examining the NOL carryback (interest deduction) provision in columns 1-3 (4-6). First, we include only the benefit materiality proxy (columns 1 and 4). In both models, we find that it is strongly associated with the propensity to discuss the CARES tax provision, consistent with firms being likelier to discuss the tax provision when the benefit is more material. When adding the reputational cost variables (columns 2 and 6), we find that firms with greater pre-pandemic payouts and during-pandemic lobbying are less likely to discuss the interest deduction provisions. Interestingly, we find that larger firms are more likely to discuss the interest deduction provisions. While inconsistent a political

15 Additional interest expense is calculated as: 0.2 times 2019 EBITDA (if the firm's 2019 interest expense is greater than 50\% of 2019 EBIDTA), 2019 interest expense minus 0.3 times 2019 EBITDA (if the firm's 2019 interest expense is less than or equal to 50\% of 2019 EBITDA), or zero (if the firm's 2019 EBITDA is zero or negative).

16 We use this period as the NOL firms by definition have losses in either 2018 or 2019, and therefore do not have well defined ETRs during these years. 
cost story, it is consistent with larger firms having more sophisticated tax departments, which enables better tax planning (Barrios and Gallemore 2019). ${ }^{17}$ On the other hand, we find little association between these variables and the propensity to discuss the NOL carryback provision. Finally, we add sector and state-level variables in columns 3 and 6. Results are generally unchanged, except that we find some evidence that firms in sectors experiencing higher stock returns (firms in states with more COVID-19 cases per capita) are less (more) likely to discuss the interest deduction provision. These results could also be consistent with a reputational cost story: firms in sectors with greater stock performance or in states with fewer COVID-19 cases are more reluctant to disclose CARES tax benefits. Overall, Table 3 provides some evidence that firms acted strategically in discussing the interest deduction provision. However, these results are subject to important caveats. First, we rely on accounting information to estimate whether the firm is likely to benefit from the provision and the materiality of any expected benefit, while the actual applicability and benefit depends on tax information (e.g., taxable income and prior taxes paid). Thus, our classification and materiality estimates may be measured with error. Second, our proximity to CARES means that some firms may still be evaluating the Act and will ultimately discuss the tax provisions in a later filing, although the simplicity of these tax provisions casts doubt on this explanation.

\section{Conclusion}

We provide initial large-sample evidence regarding the CARES corporate tax provisions. In contrast to other CARES provisions specifically targeting individuals and small businesses, the tax provisions were applicable to a wider set of firms. Some claimed that these tax provisions provided immediate liquidity and encouraged employee retention, while others argued that mainly benefitted shareholders of large corporations. To shed light on the use of these tax provisions, we analyze SEC filings in which publicly-listed U.S. firms discuss factors that materially impact their operations. We find that only 38 percent of firms mention at least one CARES tax provision, and that this is primarily driven by the NOL

17 In untabulated analyses, we also include institutional share ownership and analyst following to proxy for the demand for information. We do not find evidence that firms facing greater information demands were more or less likely to discuss the tax provisions. 
carryback provision. We find that firms operating in states and sectors with greater unemployment increases were more likely to discuss the retention credit, suggesting that this provision potentially benefitted employees in these states and industries. In contrast, we find that the most prominent CARES tax provision, NOL carryback rule, was more likely to be discussed by firms with lower stock returns during the pandemic. Our findings have implications for policymakers trying to mitigate the economic fallout from the COVID19 pandemic specifically, and economic crises more generally. Our findings suggest that the benefits of the CARES tax provisions, and in particular the NOL carryback, may have primarily flowed to firms with declining during-pandemic stock prices, rather than the states and sectors whose labor forces were most negatively impacted by the pandemic. 


\section{References}

Auerbach, A. J. 2009. Implementing the new fiscal policy activism. American Economic Review 99 (2):543549.

Auerbach, A. J., and K. A. Hassett. 2002. Fiscal policy and uncertainty. International Finance 5 (2):229249.

Ayers, B. C., C. M. Schwab, and S. Utke. 2015. Noncompliance with mandatory disclosure requirements: The magnitude and determinants of undisclosed permanently reinvested earnings. The Accounting Review 90 (1):59-93.

Baker, S. R., R. A. Farrokhnia, S. Meyer, M. Pagel, and C. Yannelis. 2020. Income, liquidity, and the consumption response to the 2020 economic stimulus payments. Working paper, National Bureau of Economic Research.

Barrios, J., and J. Gallemore. 2019. Tax-Related Human Capital: Evidence from Employee Movements. Working paper, University of Chicago.

Barrios, J. M., M. Minnis, W. C. Minnis, and J. Sijthoff. 2020. Assessing the Payroll Protection Program: A Framework and Preliminary Results. Working paper, University of Chicago.

Bartik, A. W., M. Bertrand, Z. B. Cullen, E. L. Glaeser, M. Luca, and C. T. Stanton. 2020. How are small businesses adjusting to covid-19? early evidence from a survey. Working paper, National Bureau of Economic Research.

Bjorhus, J., and P. Kennedy. 2020. CARES Act tax breaks a jackpot for huge companies, wealthy business owners. The Star Tribune, June 2, 2020.

Cochrane, E., and N. Fandos. 2020. Senate Approves \$2 Trillion Stimulus After Bipartisan Deal. New York Times, March 25, 2020.

Eilbott, P. 1966. The effectiveness of automatic stabilizers. The American Economic Review 56 (3):450465.

Evers-Hillstrom, K. 2020. Coronavirus stimulus spurs near-record first-quarter lobbying spending. Available at https://www.opensecrets.org/news/2020/04/coronavirus-stimulus-spurs-lobbying/.

Fischer, B., and K. Payne. 2020. How Lobbyists Robbed Small Business Relief Loans. New York Times, April 30, 2020.

Ganong, P., P. J. Noel, and J. S. Vavra. 2020. US Unemployment Insurance Replacement Rates During the Pandemic. Working paper, National Bureau of Economic Research.

Gleason, C. A., and L. F. Mills. 2002. Materiality and contingent tax liability reporting. The Accounting Review 77 (2):317-342.

Granja, J., C. Makridis, C. Yannelis, and E. Zwick. 2020. Did the Paycheck Protection Program Hit the Target? Working paper, National Bureau of Economic Research.

Gross, T. 2020. How The CARES Act Became A Tax-Break Bonanza For The Rich, Explained. NPR, April 30, 2020.

Heitzman, S., C. Wasley, and J. Zimmerman. 2010. The joint effects of materiality thresholds and voluntary disclosure incentives on firms' disclosure decisions. Journal of Accounting and Economics 49 (12):109-132.

Humphries, J. E., C. Neilson, and G. Ulyssea. 2020. The evolving impacts of COVID-19 on small businesses since the CARES Act.

Lerman, A., and J. Livnat. 2010. The new Form 8-K disclosures. Review of Accounting Studies 15 (4):752778.

Romer, C. D., and D. H. Romer. 1994. What ends recessions? NBER macroeconomics annual 9:13-57.

Rubin, R. 2020. Democrats Revisit Stimulus Bill's Tax Breaks for Businesses. The Wall Street Journal, May 6, 2020.

Sloan, A. 2020. The CARES Act Sent You a \$1,200 Check but Gave Millionaires and Billionaires Far More. ProPublica, June 8, 2020.

Zimmerman, J. L. 1983. Taxes and firm size. Journal of Accounting and Economics 5:119-149.

Zwick, E. 2018. The costs of corporate tax complexity. Working paper, National Bureau of Economic Research. 
Figure 1: SEC filings with CARES discussions, over time and by type

This figure presents evidence on the timing and filing types containing discussion of CARES. Panel A presents the number of cumulative filings by each date in our sample period, Panel B presents the percentage of filings of each filing type $(10 \mathrm{Q}, 10 \mathrm{~K}$, or $8 \mathrm{~K})$. In each panel, we present these data separately for filings containing any CARES discussion, a discussion of a CARES loan program, or a discussion of a CARES tax provision.

\section{Panel A: Number of cumulative filings over time, by CARES discussion category}

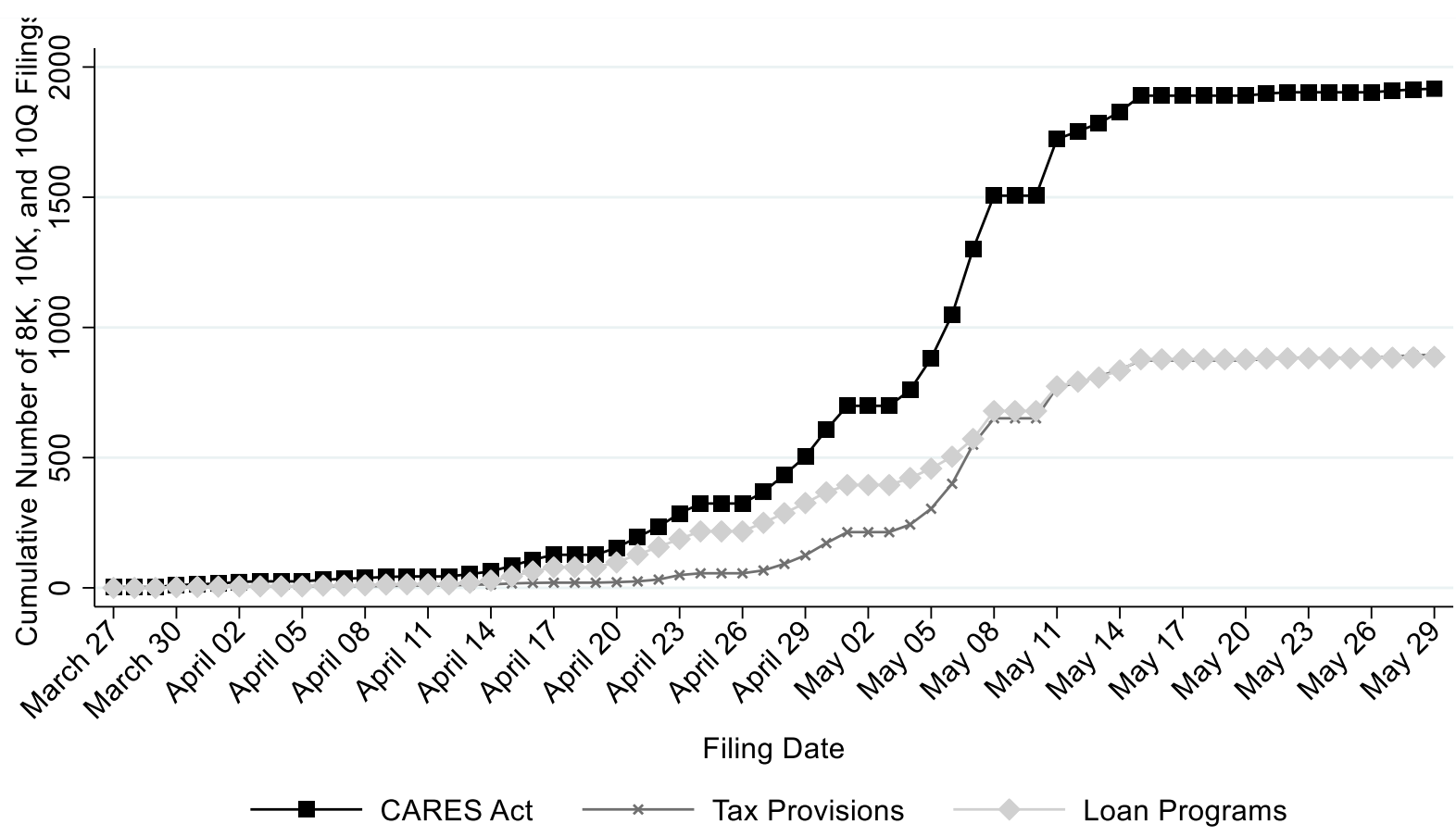

Panel B: Percentage of each filing type, by CARES discussion category

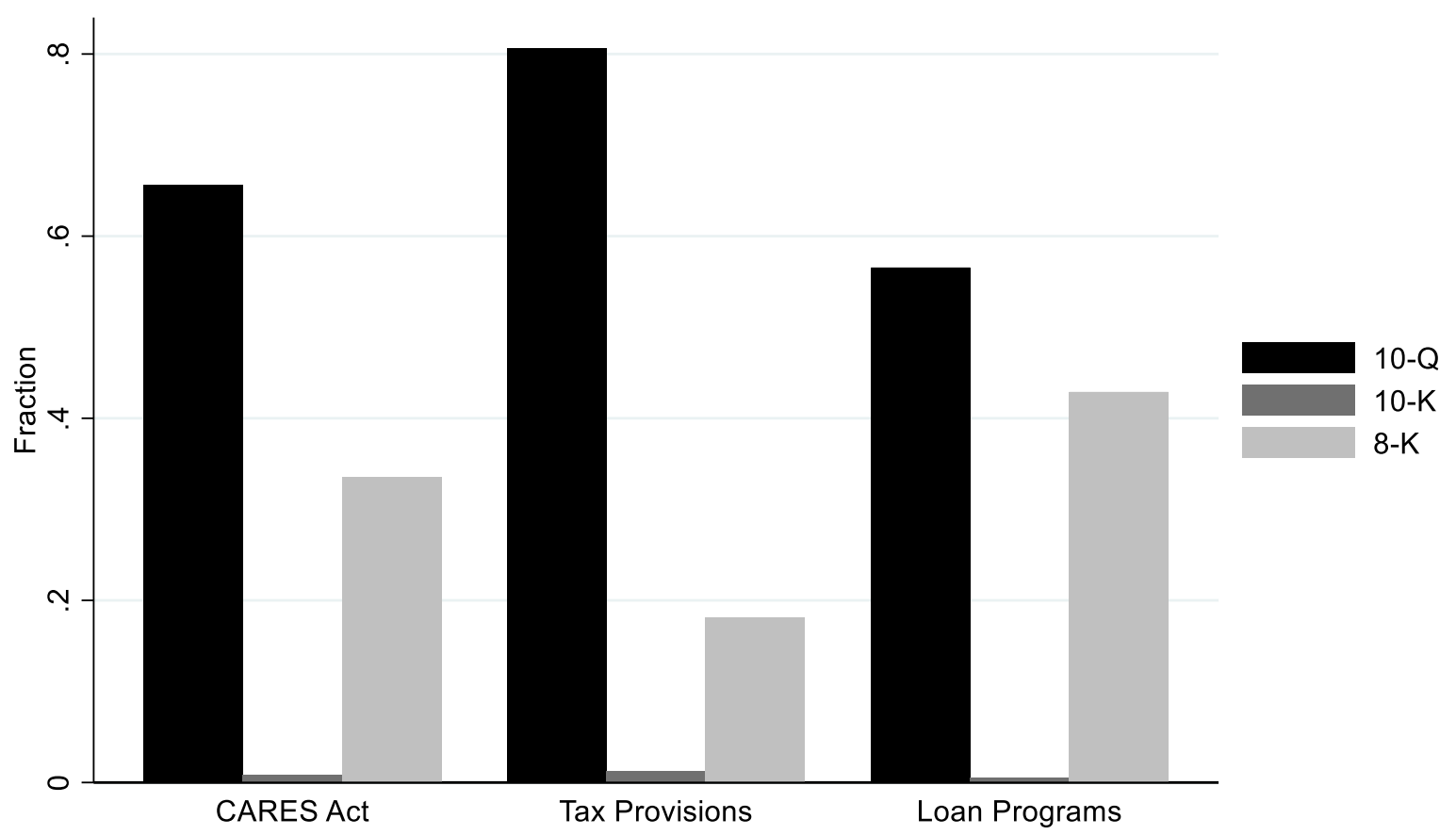




\section{Figure 2: Frequency of CARES tax provision discussions}

This figure presents the percentage of firms with at least one SEC filing during our sample period that contains at least one discussion of a CARES tax provision, either overall or by type of tax provision.

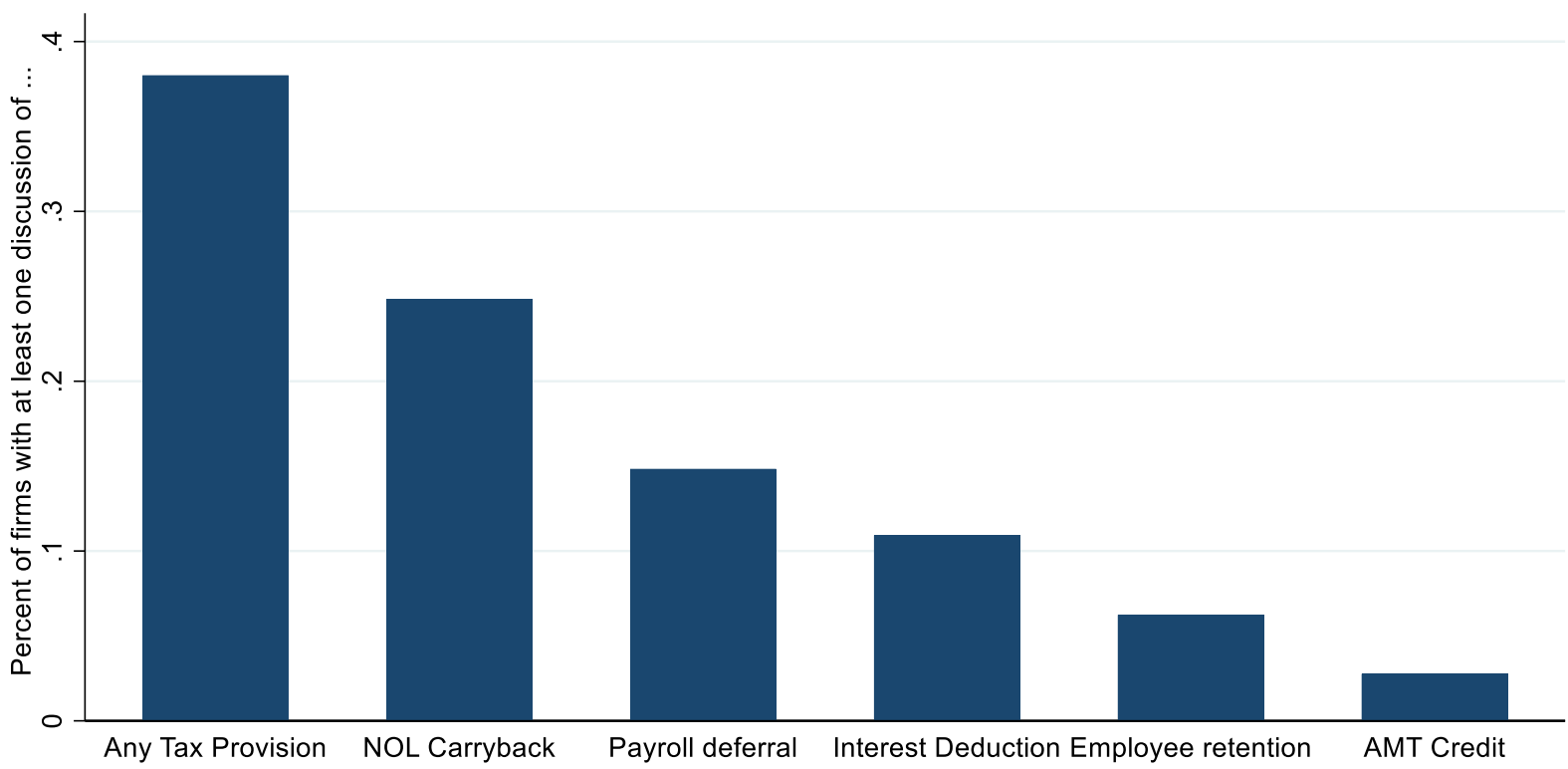


Figure 3: Association between sector-level COVID-19 impact and CARES tax provision discussions This figure presents a scatterplot of the percentage of firms in a sector discussing at least one CARES tax provision by the sector-level value-weighted stock returns from January 1 to March 24 (Panel A) or by the change in the sectorlevel unemployment rate from December 2019 to April 2020 (Panel B). We define sector using two-digit SIC membership in Panel A and the BLS sector definitions in Panel B. Each panel requires at least 10 firms per sector.

Panel A: Percent of firms discussing a CARES tax provision and sector-level during-pandemic stock returns

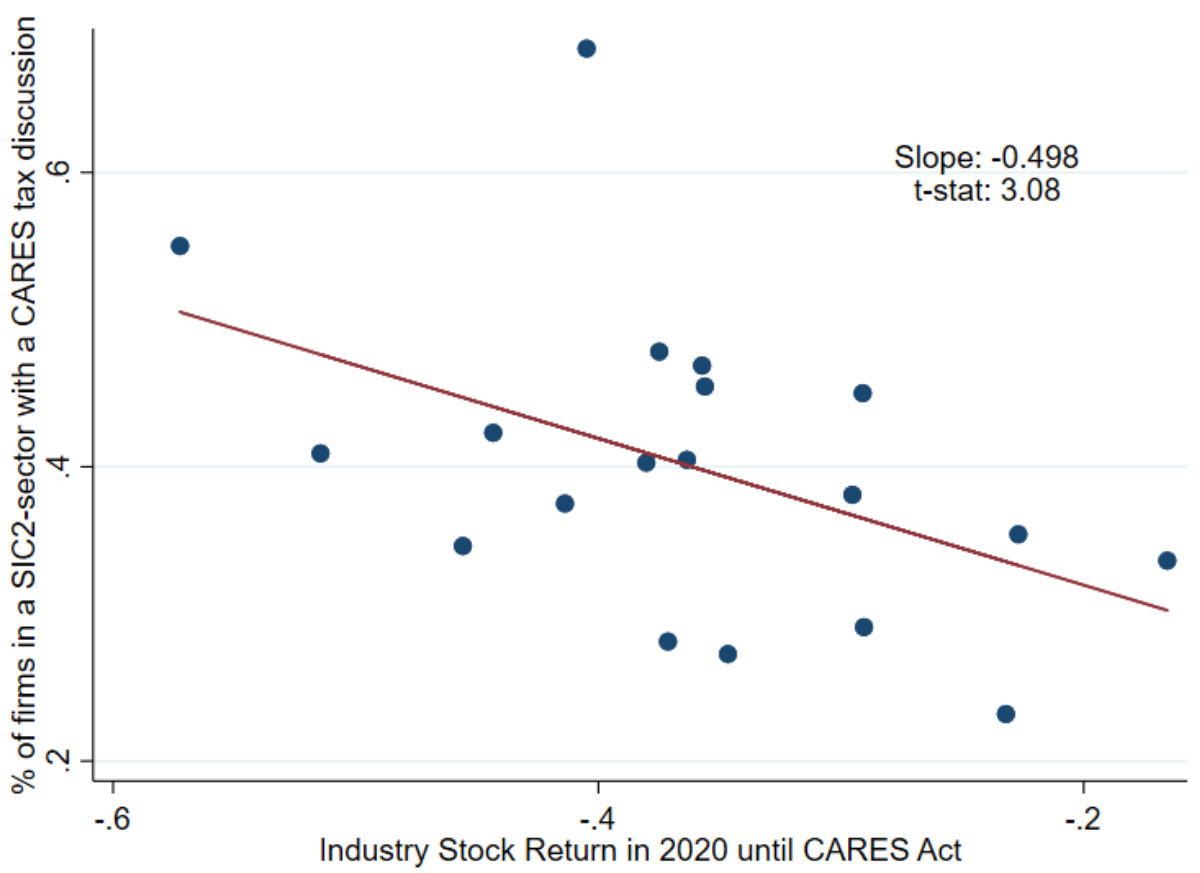

Panel B: Percent of firms discussing a CARES tax provision and sector-level during-pandemic change in unemployment

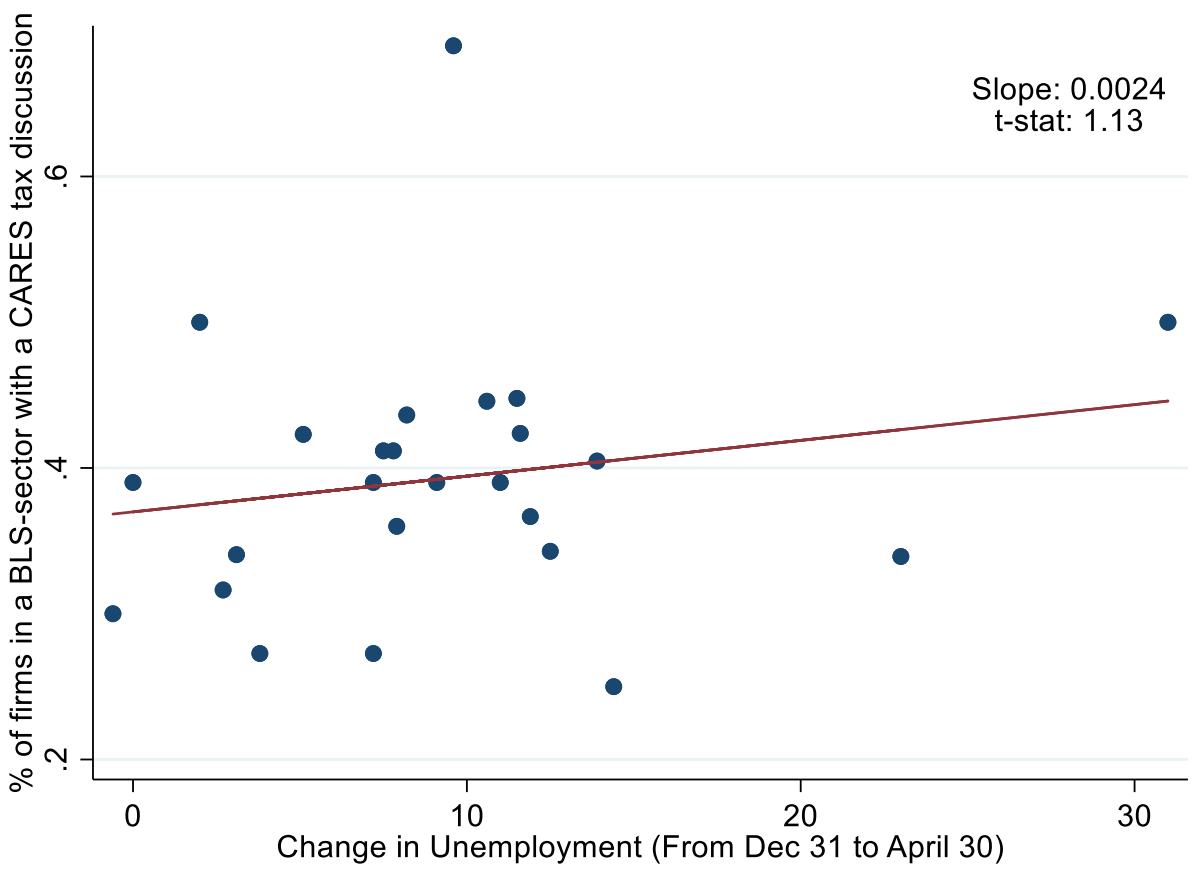


Figure 4: Association between state-level COVID-19 impact and CARES tax provision discussions This figure presents a scatterplot of the percentage of firms in a sector discussing at least one CARES tax provision by the sector-level value-weighted stock returns from January 1 to April 30 (Panel A) or by the change in the sectorlevel unemployment rate (Panel B). We define sector by two-digit SIC code in Panel A and using the BLS sector definitions in Panel B. Each panel requires at least 10 firms per sector.

\section{Panel A: Percent of firms discussing a CARES tax provision and state-level COVID cases per capita}

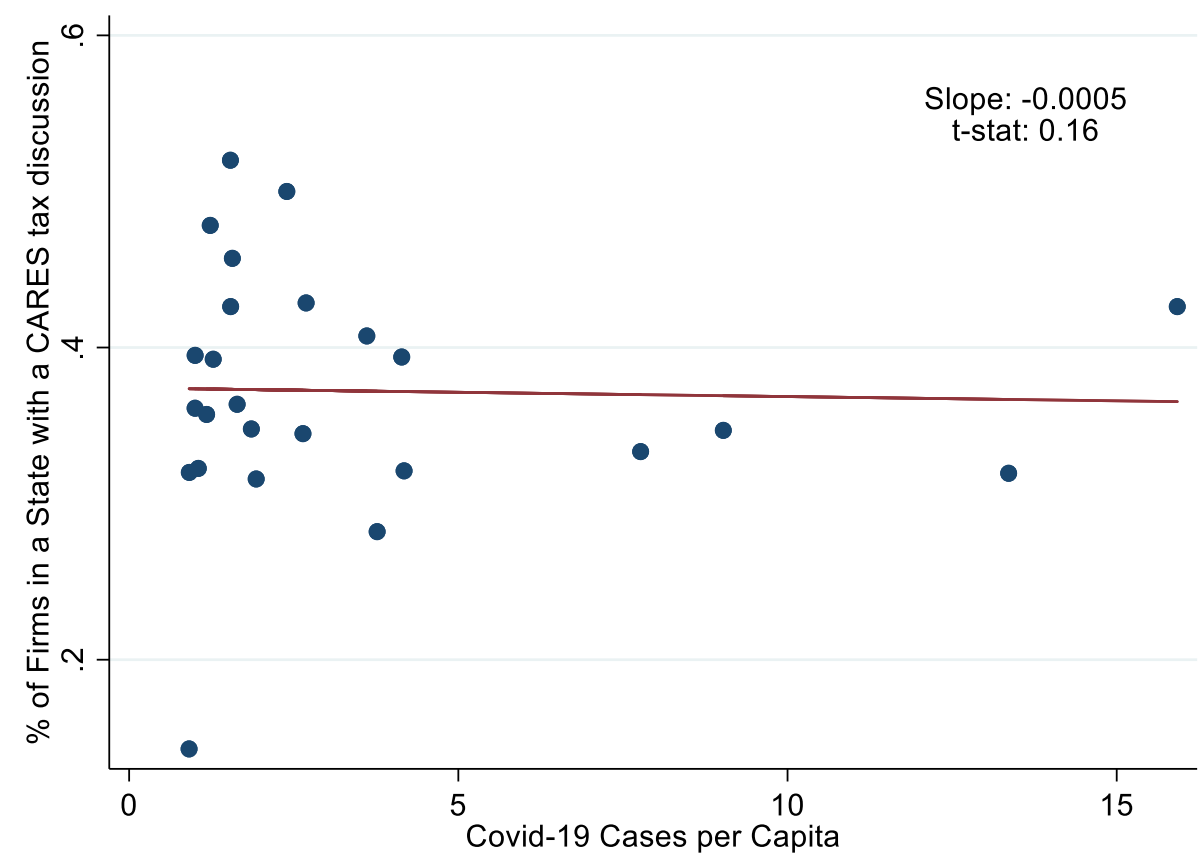

Panel B: Percent of firms discussing a CARES tax provision and state-level during-pandemic change in unemployment

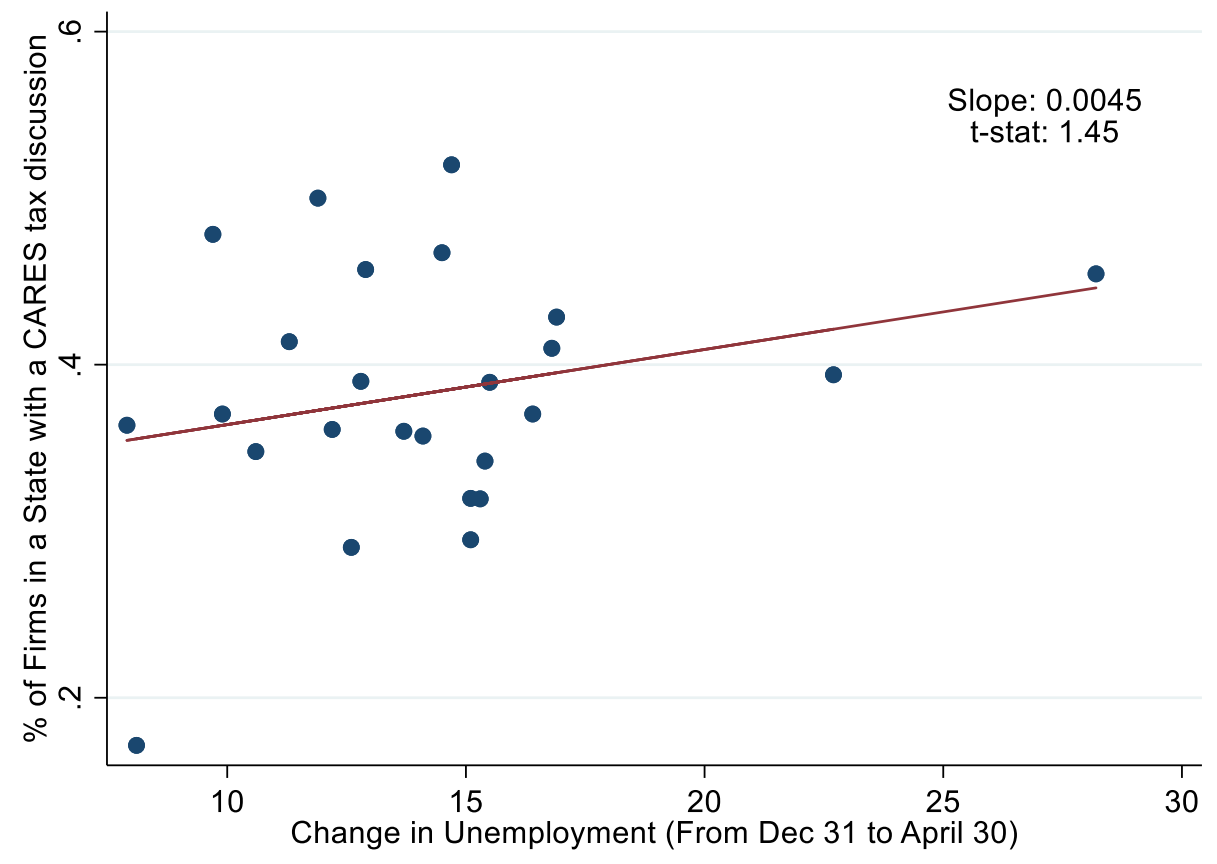


Table 1: Descriptive statistics

This table presents the descriptive statistics for the variables used in our analyses. Variable definitions are presented in Appendix B.

Panel A: Main variables

\begin{tabular}{lrrrrr}
\hline Variable & Mean & Std. Dev. & P25 & Median & P75 \\
\hline Tax Provision & 0.38 & 0.49 & 0 & 0 & 1 \\
NOL Carryback & 0.25 & 0.43 & 0 & 0 & 0 \\
Payroll Deferral & 0.15 & 0.36 & 0 & 0 & 0 \\
Retention Credit & 0.06 & 0.24 & 0 & 0 & 0 \\
Interest Deduction & 0.11 & 0.31 & 0 & 0 & 0 \\
AMT Credit & 0.03 & 0.16 & 0 & 0 & 0 \\
Size & 6.89 & 2.21 & 5.34 & 7.03 & 8.43 \\
Loss 18/19 & 0.26 & 0.44 & 0 & 0 & 1 \\
Leverage & 0.32 & 0.31 & 0.12 & 0.30 & 0.45 \\
Employees & 3.22 & 4.84 & 0.76 & 1.92 & 3.65 \\
Firm Stock Return & -0.16 & 0.65 & -0.41 & -0.16 & 0.04 \\
Cash Holdings & 0.22 & 0.26 & 0.03 & 0.10 & 0.32 \\
Sector Stock Return & -0.32 & 0.12 & -0.38 & -0.29 & -0.23 \\
S Sector Unemployment & 8.61 & 7.69 & 3.10 & 7.80 & 10.80 \\
State COVID-19 Cases & 3.97 & 4.47 & 1.28 & 1.57 & 4.18 \\
A State Unemployment & 10.54 & 2.78 & 9.30 & 10.70 & 11.70 \\
\hline
\end{tabular}

Panel B: Disclosure test variables

\begin{tabular}{lrrrrr}
\hline Variable & \multicolumn{1}{c}{ Mean } & Std. Dev. & \multicolumn{1}{c}{ P25 } & \multicolumn{1}{c}{ Median } & \multicolumn{1}{c}{ P75 } \\
\hline NOL Carryback Materiality & 0.01 & 0.03 & 0.00 & 0.00 & 0.00 \\
Interest Deduction Materiality & 0.00 & 0.01 & 0.00 & 0.00 & 0.00 \\
Payout & 0.03 & 0.07 & 0.00 & 0.00 & 0.02 \\
Lobbying & 10.53 & 3.67 & 10.82 & 11.29 & 12.16 \\
Lobbying $(\$)$ & 246,518 & 579,306 & 50,000 & 80,000 & 191,000 \\
\hline
\end{tabular}


Table 2: Examining determinants of CARES tax provision discussions

This table presents the results from regressing variables capturing the discussion of CARES tax provisions in SEC filings on a set of firm-level, sector-level, and state-level variables using a linear probability model. In column 1, the dependent variable is Tax Provision, an indicator variable equal to one if the firm discussed any CARES corporate tax provision at least one in its SEC filings from March 27 through May 31, and zero otherwise. In columns 5 through 6, we use indicator variables that capture the discussions of the specific CARES tax provisions (NOL Carryback, Payroll Deferral, Retention Credit, Interest Deduction, or AMT Credit). All variables are defined in Appendix B. The unit of observation is the firm. Below the coefficient estimates, we present standard errors clustered at the state-sector level (where sector is defined by SIC 2 code). $* * *, * *, *$ indicates that the coefficient estimate is statistically significant at the 1,5 , and 10 percent levels, respectively.

\begin{tabular}{|c|c|c|c|c|c|}
\hline Dependent variable: & $\begin{array}{c}\text { (1) } \\
\text { Tax } \\
\text { Provision }\end{array}$ & $\begin{array}{c}(2) \\
\text { NOL } \\
\text { Carryback }\end{array}$ & $\begin{array}{c}\text { (3) } \\
\text { Payroll } \\
\text { Deferral }\end{array}$ & $\begin{array}{c}(4) \\
\text { Retention } \\
\text { Credit }\end{array}$ & $\begin{array}{c}\text { (5) } \\
\text { Interest } \\
\text { Deduction }\end{array}$ \\
\hline Size & $\begin{array}{l}-0.0052 \\
(0.0058)\end{array}$ & $\begin{array}{l}-0.0081 * \\
(0.0046)\end{array}$ & $\begin{array}{c}0.0038 \\
(0.0051)\end{array}$ & $\begin{array}{c}-0.0007 \\
(0.0032)\end{array}$ & $\begin{array}{c}-0.0071 * * \\
(0.0034)\end{array}$ \\
\hline Loss $18 / 19$ & $\begin{array}{c}0.1346 * * * \\
(0.0307)\end{array}$ & $\begin{array}{c}0.1313 * * * \\
(0.0292)\end{array}$ & $\begin{array}{l}-0.0006 \\
(0.0180)\end{array}$ & $\begin{array}{l}-0.0170 \\
(0.0111)\end{array}$ & $\begin{array}{c}0.0104 \\
(0.0176)\end{array}$ \\
\hline Leverage & $\begin{array}{l}-0.0209 \\
(0.0365)\end{array}$ & $\begin{array}{l}-0.0050 \\
(0.0283)\end{array}$ & $\begin{array}{l}-0.0166 \\
(0.0216)\end{array}$ & $\begin{array}{c}0.0046 \\
(0.0149)\end{array}$ & $\begin{array}{c}0.0679 * * \\
(0.0330)\end{array}$ \\
\hline Employees & $\begin{array}{c}0.0047 * \\
(0.0026)\end{array}$ & $\begin{array}{c}0.0008 \\
(0.0020)\end{array}$ & $\begin{array}{c}0.0085 * * * \\
(0.0025)\end{array}$ & $\begin{array}{c}0.0006 \\
(0.0013)\end{array}$ & $\begin{array}{l}-0.0002 \\
(0.0014)\end{array}$ \\
\hline Firm Stock Return & $\begin{array}{l}-0.0192 \\
(0.0215)\end{array}$ & $\begin{array}{c}-0.0412 * * \\
(0.0170)\end{array}$ & $\begin{array}{l}-0.0168 \\
(0.0123)\end{array}$ & $\begin{array}{l}-0.0044 \\
(0.0076)\end{array}$ & $\begin{array}{l}-0.0013 \\
(0.0123)\end{array}$ \\
\hline Cash Holdings & $\begin{array}{c}-0.0174 \\
(0.0612)\end{array}$ & $\begin{array}{c}0.0000 \\
(0.0515)\end{array}$ & $\begin{array}{c}-0.0660 * * \\
(0.0335)\end{array}$ & $\begin{array}{c}-0.0088 \\
(0.0249)\end{array}$ & $\begin{array}{c}-0.0626^{*} \\
(0.0356)\end{array}$ \\
\hline Sector Stock Return & $\begin{array}{c}-0.3966 * * * \\
(0.1103)\end{array}$ & $\begin{array}{c}-0.2962 * * * \\
(0.0942)\end{array}$ & $\begin{array}{l}-0.1791 * \\
(0.0970)\end{array}$ & $\begin{array}{c}-0.0107 \\
(0.0527)\end{array}$ & $\begin{array}{l}-0.0862 \\
(0.0784)\end{array}$ \\
\hline$\Delta$ Sector Unemployment & $\begin{array}{c}0.0006 \\
(0.0015)\end{array}$ & $\begin{array}{c}0.0012 \\
(0.0015)\end{array}$ & $\begin{array}{c}0.0012 \\
(0.0013)\end{array}$ & $\begin{array}{c}0.0026 * * \\
(0.0010)\end{array}$ & $\begin{array}{c}0.0015 \\
(0.0013)\end{array}$ \\
\hline State COVID-19 Cases & $\begin{array}{c}0.0015 \\
(0.0025)\end{array}$ & $\begin{array}{c}0.0033 \\
(0.0023)\end{array}$ & $\begin{array}{l}-0.0005 \\
(0.0019)\end{array}$ & $\begin{array}{c}0.0007 \\
(0.0015)\end{array}$ & $\begin{array}{c}0.0039 * * \\
(0.0016)\end{array}$ \\
\hline$\Delta$ State Unemployment & $\begin{array}{c}0.0035 \\
(0.0043)\end{array}$ & $\begin{array}{c}0.0048 \\
(0.0036) \\
\end{array}$ & $\begin{array}{c}0.0022 \\
(0.0030) \\
\end{array}$ & $\begin{array}{c}0.0037 * * \\
(0.0018)\end{array}$ & $\begin{array}{c}0.0021 \\
(0.0027) \\
\end{array}$ \\
\hline Observations & 1,813 & 1,813 & 1,813 & 1,813 & 1,813 \\
\hline Adjusted R-squared & 0.017 & 0.024 & 0.026 & 0.007 & 0.012 \\
\hline
\end{tabular}




\section{Table 3: Examining strategic discussion of CARES tax provisions}

This table presents the results from regressing variables capturing the discussion of NOL Carryback (columns 1 and 2) and Interest Deduction (columns 3 and 4), respectively on a set of firm-level variables using a linear probability model. All variables are defined in Appendix B. The unit of observation is the firm. Below the coefficient estimates, we present robust standard errors. $* * *, * *, *$ indicates that the coefficient estimate is statistically significant at the 1 , 5 , and 10 percent levels, respectively.

\begin{tabular}{|c|c|c|c|c|c|c|}
\hline \multirow{3}{*}{$\begin{array}{l}\text { Dependent variable: } \\
\text { NOL Carryback Materiality }\end{array}$} & (1) & (2) & (3) & \multirow{2}{*}{\multicolumn{3}{|c|}{$\begin{array}{c}(5) \\
\text { Interest Deduction }\end{array}$}} \\
\hline & \multicolumn{3}{|c|}{ NOL Carryback } & & & \\
\hline & $\begin{array}{l}0.0477 * * \\
(0.0192)\end{array}$ & $\begin{array}{l}0.0470 * * \\
(0.0202)\end{array}$ & $\begin{array}{l}0.0458 * * \\
(0.0206)\end{array}$ & & & \\
\hline Interest Deduction Materiality & & & & $\begin{array}{c}0.0653 * * * \\
(0.0159)\end{array}$ & $\begin{array}{c}0.0496 * * * \\
(0.0154)\end{array}$ & $\begin{array}{c}0.0452 * * * \\
(0.0154)\end{array}$ \\
\hline Size & & $\begin{array}{c}0.0150 \\
(0.0117)\end{array}$ & $\begin{array}{c}0.0141 \\
(0.0123)\end{array}$ & & $\begin{array}{c}0.0174 * * * \\
(0.0051)\end{array}$ & $\begin{array}{c}0.0143 * * * \\
(0.0053)\end{array}$ \\
\hline Payout & & $\begin{array}{l}-0.3334 \\
(0.3889)\end{array}$ & $\begin{array}{l}-0.3581 \\
(0.3931)\end{array}$ & & $\begin{array}{c}-0.3076 * * * \\
(0.1087)\end{array}$ & $\begin{array}{c}-0.3172 * * * \\
(0.1074)\end{array}$ \\
\hline Lobbying & & $\begin{array}{c}0.0058 \\
(0.0067)\end{array}$ & $\begin{array}{c}0.0050 \\
(0.0067)\end{array}$ & & $\begin{array}{c}-0.0141 * * * \\
(0.0039)\end{array}$ & $\begin{array}{c}-0.0148 * * * \\
(0.0039)\end{array}$ \\
\hline Low ETR & & $\begin{array}{l}-0.1021 \\
(0.0793)\end{array}$ & $\begin{array}{l}-0.0952 \\
(0.0788)\end{array}$ & & $\begin{array}{c}0.0072 \\
(0.0507)\end{array}$ & $\begin{array}{l}-0.0073 \\
(0.0506)\end{array}$ \\
\hline Firm Stock Return & & $\begin{array}{l}-0.0080 \\
(0.0278)\end{array}$ & $\begin{array}{l}-0.0135 \\
(0.0276)\end{array}$ & & $\begin{array}{c}0.0221 \\
(0.0154)\end{array}$ & $\begin{array}{c}0.0163 \\
(0.0155)\end{array}$ \\
\hline Sector Stock Return & & & $\begin{array}{l}-0.2470 \\
(0.2485)\end{array}$ & & & $\begin{array}{l}-0.2946 * \\
(0.1540)\end{array}$ \\
\hline$\triangle$ Sector Unemployment & & & $\begin{array}{l}-0.0016 \\
(0.0034)\end{array}$ & & & $\begin{array}{c}0.0009 \\
(0.0023)\end{array}$ \\
\hline State COVID-19 Cases & & & $\begin{array}{c}0.0057 \\
(0.0050)\end{array}$ & & & $\begin{array}{l}0.0057 * * \\
(0.0027)\end{array}$ \\
\hline$\triangle$ State Unemployment & & & $\begin{array}{l}-0.0129 * \\
(0.0076)\end{array}$ & & & $\begin{array}{l}-0.0010 \\
(0.0045)\end{array}$ \\
\hline Observations & 461 & 461 & 461 & 842 & 842 & 842 \\
\hline Adjusted R-squared & 0.013 & 0.011 & 0.012 & 0.035 & 0.061 & 0.070 \\
\hline
\end{tabular}

